\title{
The oldest predaceous water bugs (Insecta, Heteroptera, Belostomatidae), with implications for paleolimnology of the Triassic Cow Branch Formation
}

\author{
Julia Criscione $^{1}$ and David Grimaldi ${ }^{2}$ \\ ${ }^{1}$ Department of Earth and Planetary Sciences, Rutgers University, 610 Taylor Road, Piscataway, NJ, 08854, USA 〈juliecriscione@gmail.com〉 \\ ${ }^{2}$ Division of Invertebrate Zoology, American Museum of Natural History, Central Park West at $79^{\text {th }}$ St, New York, NY, 10024, USA \\ 〈grimaldi@amnh.org〉
}

\begin{abstract}
A new genus and species of predaceous water bugs, Triassonepa solensis $\mathrm{n}$. gen. n. sp., is described from the Triassic Cow Branch Formation of Virginia and North Carolina (USA) based on $~ 36$ adult specimens and 51 nymphs. This species is the oldest known member of the extant family Belostomatidae. It is placed in a new genus based on the unique structure of the raptorial foreleg, in which the tarsus is elongate and opposed to the tibia + femur. The fossil record of this family is reviewed and the paleoenvironmental implications of the species assemblage preserved in the Cow Branch Formation are discussed.
\end{abstract}

\section{Introduction}

The Heteroptera, or sucking bugs, have a long fossil record, potentially spanning back to the Permian. The first putative heteropteran from this period is Paraknightia magnifica Evans, 1943 from New South Wales (Evans, 1950). However, the first definitive heteropteran, Arlecoris louisi Shcherbakov, 2010, was recently described from the earliest Middle Triassic (early Anisian) of the northern Vosges Mountains of France. This species is also the earliest member of the infraorder Nepomorpha Popov, 1968, a group containing the majority of truly aquatic heteropterans (Belostomatidae Leach, 1815; Nepidae Latreille, 1802; Naucoridae Leach, 1815; Corixidae Leach, 1815; and Notonectidae Leach, 1815). The Nepomorpha have the best fossil record of all Heteroptera (Grimaldi and Engel, 2005), no doubt because of their aquatic habits, but the fossil record of belostomatids is not yet well studied. Modern Belostomatidae are medium- $(9 \mathrm{~mm})$ to very large-sized (110 mm adult body length) swimming bugs that are efficient predators, grabbing prey with raptorial forelegs, injecting potent salivary secretions, and siphoning out the liquefied internal tissues of their prey with a sharp beak.

The earliest described belostomatid fossils are from the Jurassic, when the family first diversified. The oldest of these is Odrowazicoris polonicus Popov, 1996, an isolated wing in Hettangian-age beds of the Holy Cross Mountains of Poland. A number of other Jurassic species have been described from Europe and the United States, including: Tarsabedus menkei Popov, Dolling, and Whalley, 1994; Aenictobelostoma primitivum Polhemus, 2000; Stygeonepa foersteri Popov, 1971; and Nettelstedtia breitkreutzi Popov, Rust, and Brauckmann, 2000. The Early Cretaceous also harbored diverse species and genera, including three taxa from the Crato Formation Plattenkalk of Brazil, and a species possessing unique paddle-shaped metathoracic legs, Iberonepa romerali Martínez-Delclòs, Nel, and Popov, 1995, from Las Hoyas, Spain.
Though belostomatids are widespread in Cenozoic sediments, many are still undescribed, including a Paleocene specimen from Alberta, Canada (Mitchell and Wighton, 1979), two unnamed early Eocene specimens from Denmark (Larsson, 1975; Rust and Ansorge, 1996), and a late Oligocene specimen from Germany (Wedmann, 2000). The extant genus Lethocerus Mayr, 1853 became fairly diverse during the Miocene, with two species (L. sulcifemoralis Ríha and Kukalová, 1967, and L. turgaicus Popov, 1971) found in the Oligocene-Miocene of the Czech Republic and the Miocene of Russia, respectively. Additionally, two modern species, Lethocerus americanus Leidy, 1847 and Belostoma bakeri Montandon, 1913, are reported to occur in Late Pleistocene asphalt deposits of California (Miller, 1983). See Table 1 for a complete list of fossil belostomatid species.

Today, belostomatids have a worldwide distribution, although the majority of species are found in the tropics. They are represented by three subfamilies consisting of nine genera and 146 species (Schuh and Slater, 1995). The subfamily Belostomatinae Lauck and Menke, 1961, is by far the largest group within Belostomatidae and contains six genera: Abedus Stål, 1862; Appasus Amyot and Serville, 1843 (Polhemus, 1995); Belostoma Latreille, 1807; Diplonychus Laporte, 1833; Hydrocyrius Spinola, 1850; and Limnogeton Mayr, 1853. The subfamily Horvathiniinae Lauck and Menke, 1961, is monogeneric, consisting of nine species in the genus Horvathinia Montadon, 1911. The third subfamily, Lethocerinae Lauck and Menke, 1961, consists of three genera: Lethocerus Mayr, 1853; Benacus Stål, 1861 (Goodwyn, 2006); and Kirkaldyia Montandon, 1909 (Goodwyn, 2006).

The current belostomatid phylogeny is based on morphology and reproductive behaviors: (Lethocerinae, (Horvathiniinae (Belostomatinae))) (Lauck and Menke, 1961; Mahner, 1993; Smith, 1997). Lethocerinae is the most basal taxon because it retains many characters of Nepidae ('water scorpions'), the sister 
Table 1. List of fossil belostomatid species.

\begin{tabular}{|c|c|c|c|c|}
\hline Species & Age & Formation & Locality & Author(s); Reference \\
\hline$\overline{\text { Odrowazicoris polonicus }}$ & Early Jurassic & Zagaje & Poland & Popov, 1996 \\
\hline Tarsabedus menkei & Early Jurassic & "Lower Lias" & Dorset, England & Popov, Dolling, and Whalley, 1994 \\
\hline Lethonectes naucoroides & Early Jurassic & "Lower Lias" & Dorset, England & Popov, Dolling, and Whalley, 1994 \\
\hline Aenictobelostoma primitivum & Middle Jurassic & Todilto & New Mexico, USA & Polhemus, 2000 \\
\hline Mesobelostomum deperditum & Late Jurassic & Solnhofen & Germany & Germar, 1839; Lakshminarayana, 1984 \\
\hline Mesonepa primordialis & Late Jurassic & Solnhofen & Germany & Germar, 1839; Lakshminarayana, 1984 \\
\hline Stygeonepa foersteri & Late Jurassic & Solnhofen & Germany & Popov, 1971 \\
\hline Nettelstedtia breitkreutzi & Late Jurassic & Bed 103 & $\begin{array}{l}\text { Schwarze Quarry, } \\
\text { Nettelstedt, Germany }\end{array}$ & Popov, Rust, and Brauckmann, 2000 \\
\hline Araripebelostomum martinsnetoi & Early Cretaceous & Crato & Brazil & Nel and Paicheler, 1992 \\
\hline Neponymphes godoii & Early Cretaceous & Crato & Brazil & Zamboni, 2001 \\
\hline Lethocerus vetus & Early Cretaceous & Crato & Brazil & Nel and Waller, 2006 \\
\hline Lethopterus multinervosus & Early Cretaceous & Dzun-Bain & Mongolia & Popov, 1989 \\
\hline Sinobelostoma liui & Early Cretaceous & Huachi-Huanhe & Gansu Province, China & Chou and Hong, 1989 \\
\hline Iberonepa romerali & Early Cretaceous & La Huérguina & Las Hoyas, Spain & Martínez-Delclòs, Nel, and Popov, 1995 \\
\hline Unnamed Specimen & Paleocene & Paskapoo & Alberta, Canada & Mitchell and Wighton, 1979 \\
\hline Unnamed Specimen & early Eocene & Fur & Denmark & Larsson, 1975 \\
\hline Unnamed Specimen & early Eocene & Fur & Denmark & Rust and Ansorge, 1996 \\
\hline Lethocerus sulcifemoralis & Oligocene & Bechlejovicer Diatomite & Czech Republic & Ř́íha and Kukalová, 1967 \\
\hline Unnamed Specimen & late Oligocene & Enspel & Germany & Wedmann, 2000 \\
\hline Propoissonia beskonakensis & Oligocene-Miocene & - & Turkey & Nel and Paicheler, 1992 \\
\hline Lethocerus turgaicus & Miocene & Abrosimovka & W. Siberia, Russia & Popov, 1971 \\
\hline Manocerus stagnans & middle Miocene & Shanwang & Shandong Province, China & Zhang, 1989 \\
\hline $\begin{array}{l}\text { Diplonychus microcephalum }= \\
\quad \text { Sphaerodema microcephalum }\end{array}$ & middle Miocene & Shanwang & Shandong Province, China & Zhang and Zhang, 1994 \\
\hline Lethocerus americanus & Late Pleistocene & Rancho La Brea Asphalt & California, USA & Leidy, 1847; Miller, 1983 \\
\hline Belostoma bakeri & Late Pleistocene & McKittrick Asphalt & California, USA & Montandon, 1913; Miller, 1983 \\
\hline
\end{tabular}

group to Belostomatidae. In addition, all species of Lethocerinae are emergent-brooders, meaning that their eggs are deposited on emergent vegetation and attended to by the males. In contrast, the more derived members of Belostomatinae are back-brooders, in which eggs are deposited on the backs of their male mates. Horvathiniinae is placed between Lethocerinae and Belostomatinae because of its more intermediate morphological characteristics. Brooding behavior has not been observed in this group and its phylogenetic position is less certain (Lauck and Menke, 1961).

The relationships within subfamily Belostomatinae are mostly resolved based on morphology, with the exception of the genus Limnogeton. Its position has been questioned due to its lack of raptorial forelegs and natatorial mid and hind legs. Lauck and Menke (1961) noted the possibility that these characters may indicate a more basal position within Belostomatidae. However, it has been placed within subfamily Belostomatinae because it exhibits back-brooding behavior (Voelker, 1968). This position was supported in a recent phylogenetic analysis of Nepomorpha (Brożek, 2014).

This paper describes the earliest known species of family Belostomatidae, Triassonepa solensis $n$. gen. $n$. sp., from the Late Triassic Cow Branch Formation of southern Virginia and northern North Carolina. Based on both the species assemblage within the formation and the known habitats of modern belostomatids, probable chemical and environmental conditions of the deposit are discussed.

\section{Materials and methods}

Locality and material.-The fossils described in this study are from the Cow Branch Formation of southern Virginia and northern North Carolina, a Late Triassic (Carnian/early Norian, 230-220 Ma) deposit outcropping in the former Solite Quarry where $>30$ Van Houten cycles are preserved. Three cycles have yielded insect fossils, but one cycle has produced the majority of the insects in this formation (Olsen et al., 1978; Fraser et al., 1996). The Cow Branch Formation is significant because it preserves the oldest fauna of freshwater insects, which are preserved as thin, two-dimensional, silvery films in a matrix of very fine-grained, black shale. Preservation is often excellent, with many specimens fully articulated and microscopic details visible. In addition to 11 orders of insects (Fraser and Grimaldi, 2003; Grimaldi et al., 2005), the Solite Quarry has produced numerous amphibious reptiles (Tanytrachelos ahynis Olsen, 1979), a gliding reptile (Mecistotrachelos apeoros Fraser et al., 2007), fish fossils, dinosaur footprints, and many plant species (Olsen et al., 1978).

Methods.-Specimens were viewed using a Nikon SMZ1500 microscope, fitted with a fiber optic ring light. This non-directional, diffuse light source was necessary to illuminate the silvery, carbonized film by which the insects are preserved. In order to examine the minute details, specimens were wetted with 70\% ethanol to increase contrast between the fossil and the black shale matrix. Photographs were taken using two separate setups. Specimens viewed at the American Museum of Natural History (AMNH) were photographed with a Nikon 16MP camera and Nikon Elements NIS software on a Nikon SMZ1500 stereomicroscope. Specimens housed at the Virginia Museum of Natural History (VMNH) were photographed with a Canon 6D DSLR camera using Canon Utility 2 software. All specimen measurements were taken using ImageJ software. Total lengths of adults were measured from the anterior margin of head to the distal margin of the $7^{\text {th }}$ abdominal segment, in order to exclude the $8^{\text {th }}$ abdominal segment, which protrudes to varying degrees in different specimens.

Repositories and institutional abbreviations.-Most of the material examined in this study is housed at the Virginia Museum of Natural History (VMNH), Martinsville, Virginia, 
USA; some specimens are deposited in the American Museum of Natural History (AMNH), New York, USA.

\section{Systematic paleontology}

Suborder Heteroptera Latreille, 1810

Infraorder Nepomorpha Popov, 1968

Superfamily Nepoidea Latreille, 1802

Family Belostomatidae Leach, 1815

\section{Genus Triassonepa new genus}

Type species.-Triassonepa solensis $\mathrm{n}$. gen. $\mathrm{n}$. sp. by present designation.

Diagnosis.—As for type species, by monotypy.

Etymology.-The genus name is a combination of the prefix Triasso-, for the Triassic Period from which the genus is derived, and -nepa, a standard suffix used for the superfamily Nepoidea.

Occurrence.-Former Solite Quarry C, Eden, Rockingham County, North Carolina, USA $\left(36^{\circ} 32^{\prime} 29.6556^{\prime \prime} \mathrm{N}, 7^{\circ} 40^{\prime}\right.$ 12.8424"W); Carnian/Norian, Late Triassic, Cow Branch Formation.

Remarks.-Triassonepa $\mathrm{n}$. gen. differs from all other known extinct and extant genera of Belostomatidae by the structure of the foreleg, in which the tarsus is elongate and opposed to the tibia + femur.

Triassonepa solensis new genus new species Figures 1-5

Holotype.-VMNH 94671, male, Fig. 1.

Diagnosis._Body elongate. Head small, largely hidden beneath pronotum dorsally, with triangular clypeus. Pronotum small with concave anterior and posterior margins. Hemelytra with prominent claval suture; dense reticulations on apical third. Prothoracic legs raptorial, with elongate tarsus opposed to tibia. Metathoracic tibia and tarsus with dense setal fringe on inner (mesal) margin. Abdomen with seven visible segments (segments 2-8) and five visible pairs of spiracles.

Occurrence.-Former Solite Quarry C, Eden, Rockingham County, North Carolina, USA $\left(36^{\circ} 32^{\prime} 29.6556^{\prime \prime} \mathrm{N}, 7^{\circ} 40^{\prime}\right.$ 12.8424"W); Carnian/Norian, Late Triassic, Cow Branch Formation.

Description of Adults.-The description is based on the $\sim 36$ adult specimens collected to date (Fig. 2). Body elongate; total length (anterior margin of head, excluding clypeus, to apex of $7^{\text {th }}$ abdominal segment) $10.6-14.1 \mathrm{~mm}$ (mean $12.1 \mathrm{~mm}$ ).

Head.-Small, largely hidden beneath pronotum dorsally, with triangular clypeus. Eyes, antennae, and mouthparts not visible. Ocelli, if present, not visible.



Figure 1. Triassonepa solensis n. gen. n. sp., habitus of holotype, VMNH 94671. Scale bar is $2 \mathrm{~mm}$.

Thorax.-Pronotum small, $2.5-3.5 \mathrm{~mm}$ wide, $0.8-1.1 \mathrm{~mm}$ long, with concave anterior and posterior margins. Mesonotum width $\sim 1.6 x$ pronotum width; possible pigmentation preserved on pronotum and mesonotum. Scutellum about as wide as pronotum, but with indistinct margins. Hemelytra with fine crenulations on proximal two-thirds, reticulations on distal third; clavus and claval suture distinct; venation as shown in Figure 3 (also Fig. 4.4). Hindwing, if present, not preserved. Prothoracic legs raptorial (Fig. 4.1); femur wide at base $(\sim 1 \mathrm{~mm})$, narrowed distally, partially obscured by body; tarsus elongate and opposed to tibia, tibia and tarsus of similar width, tibia length $\sim 1.1 \mathrm{x}$ length of tarsus; tarsal claw not visible. Mesothoracic legs slender, with no setae or fringe apparent; tibia $~ 1.3 \mathrm{x}$ length of entire tarsus. Metathoracic legs slender, with dense setal fringe on inner (mesal) margin of tibia and tarsus (Fig. 4.6); few specimens with double setal fringe on tarsus (Fig. 4.8, 4.9); femur partially obscured by body; tibia length $\sim 1.2 \mathrm{x}$ tarsus length; tarsus with two segments.

Abdomen.-Broad, often obscured by hemelytra; length $(7.4-8.6 \mathrm{~mm})$ and width $(5.4-6.3 \mathrm{~mm})$ vary, likely due to diagenetic alteration; abdominal segments $2-8$ visible; dorsum with five pairs of spiracles visible on segments 3-7. Spiracle diameter ranges from 0.26 to $0.40 \mathrm{~mm}$ (mean $0.34 \mathrm{~mm}$ ). Terminalia variable, but with lateral paddle-like lobes; pair of short processes between the lobes that resemble respiratory 



Figure 2. Photographs of adult specimens of Triassonepa solensis n. gen. n. sp.: (1) VMNH 49641; (2) VMNH 53881; (3) VMNH 53880; (4) VMNH 94672. Scale bars are $2 \mathrm{~mm}$.

tubes; two specimens (VMNH 94671, Fig. 4.12, holotype; VMNH 94672, Fig. 2.4) with more elongate terminalia and two distal articulated appendages, possibly claspers.

Description of nymphs.-The description is based on 51 nymph specimens. Body oval, narrowed at anterior and posterior ends. Head small, often not preserved, no features discernable. Thorax roughly trapezoidal with dividing line between lateral halves; wing pads not visible. Prothoracic and mesothoracic legs not preserved. Few specimens with metathoracic tarsus preserved; setal fringe present, as in adults; two specimens (e.g., VMNH 54155, Fig. 5.4) with double setal fringe; claws, if present, not visible. Abdomen roughly triangular; six segments visible (segments 3-8).

Etymology.-The specific epithet is named after the former Virginia Solite Corporation quarries, from which the specimens were recovered.
Remarks.-Specimen VMNH 94671 was chosen as the holotype because of the excellent preservation of its legs (Fig. 1). It is the only specimen yet found with a preserved foreleg, and one of only two specimens with a preserved mesothoracic leg. Though this specimen has a narrower abdomen and lacks the stoutness of the other specimens, this difference in overall shape can likely be attributed to diagenesis due to its morphologic similarity to the other specimens. Additionally, it is the largest specimen $(14.10 \mathrm{~mm})$, but it is of a similar size to that of the only other male specimen (VMNH 94672, Fig. 2.4, $13.49 \mathrm{~mm}$ ). This may indicate that males of this species were larger than the females, which is unusual in the Heteroptera.

Triassonepa solensis $\mathrm{n}$. gen $\mathrm{n}$. sp. is the earliest known member of the family Belostomatidae. Unfortunately, all adult specimens are preserved in dorsal aspect, concealing many morphological characters. This is interesting because preservation of the ventral surface is quite common in other belostomatid fossils (e.g., Sinobelostoma liui, Chou and Hong, 1989; Lethocerus vetus, Nel and Waller, 2006). Triassonepa solensis n. gen. n. sp. ranges in length from $\sim 10.6-14.1 \mathrm{~mm}$, placing it on 




Figure 3. Reconstruction of Triassonepa solensis $\mathrm{n}$. gen. $\mathrm{n}$. sp. showing major morphological characters.

the small side of the range of modern belostomatids (9-110 mm; Schuh and Slater, 1995).

The head of Triassonepa solensis n. gen. n. sp. is poorly preserved in almost all specimens, preventing a detailed description at this time. The only feature often visible is the triangular clypeus. Neither compound eyes nor ocelli are preserved, although the absence of ocelli may be expected since modern belostomatids do not possess them (Lauck and Menke, 1961). The absence of preserved antennae is also expected given that the antennae of modern belostomatids are small and concealed within grooves beneath their heads (Schuh and Slater, 1995). In addition, due to the exclusive preservation of the dorsal surface, no mouthparts are visible.

The legs of Triassonepa solensis n. gen. n. sp. provide some interesting characters for comparison with modern members of the Belostomatidae. One unique character of this species is the structure of its prothoracic legs (Fig. 4.1). Though only preserved in a single specimen, the foreleg of $T$. solensis has an elongate tarsus that opposes the tibia. In contrast, modern belostomatids have a thin tibia + tarsus opposed to the femur (Fig. 4.2, 4.3). This raptorial foreleg appears to be less specialized than those of modern belostomatids. Another difference between $T$. solensis and modern belostomatids is the possession of setae on the legs. Modern belostomatids have setae on both the mesothoracic and metathoracic legs, but it appears that the mesothoracic legs of $T$. solensis lack these setae. This might suggest that instead of using these legs for swimming, they may have used them in conjunction with the forelegs to capture and hold prey. However, only three mesothoracic legs on two specimens have been recovered to date, indicating that the absence of these setae is not yet definitive. Triassonepa solensis n. gen. n. sp. does, however, possess a setal fringe on the metathoracic legs (Fig. 4.6, 4.84.10), indicating that they were specialized swimmers. It is interesting to note that a few specimens (including two nymphs) appear to have a double setal-fringe (Fig. 4.8, 4.9). It is unclear at this time whether this double-fringe is a result of the position in which they were preserved, or if these specimens are a distinct 

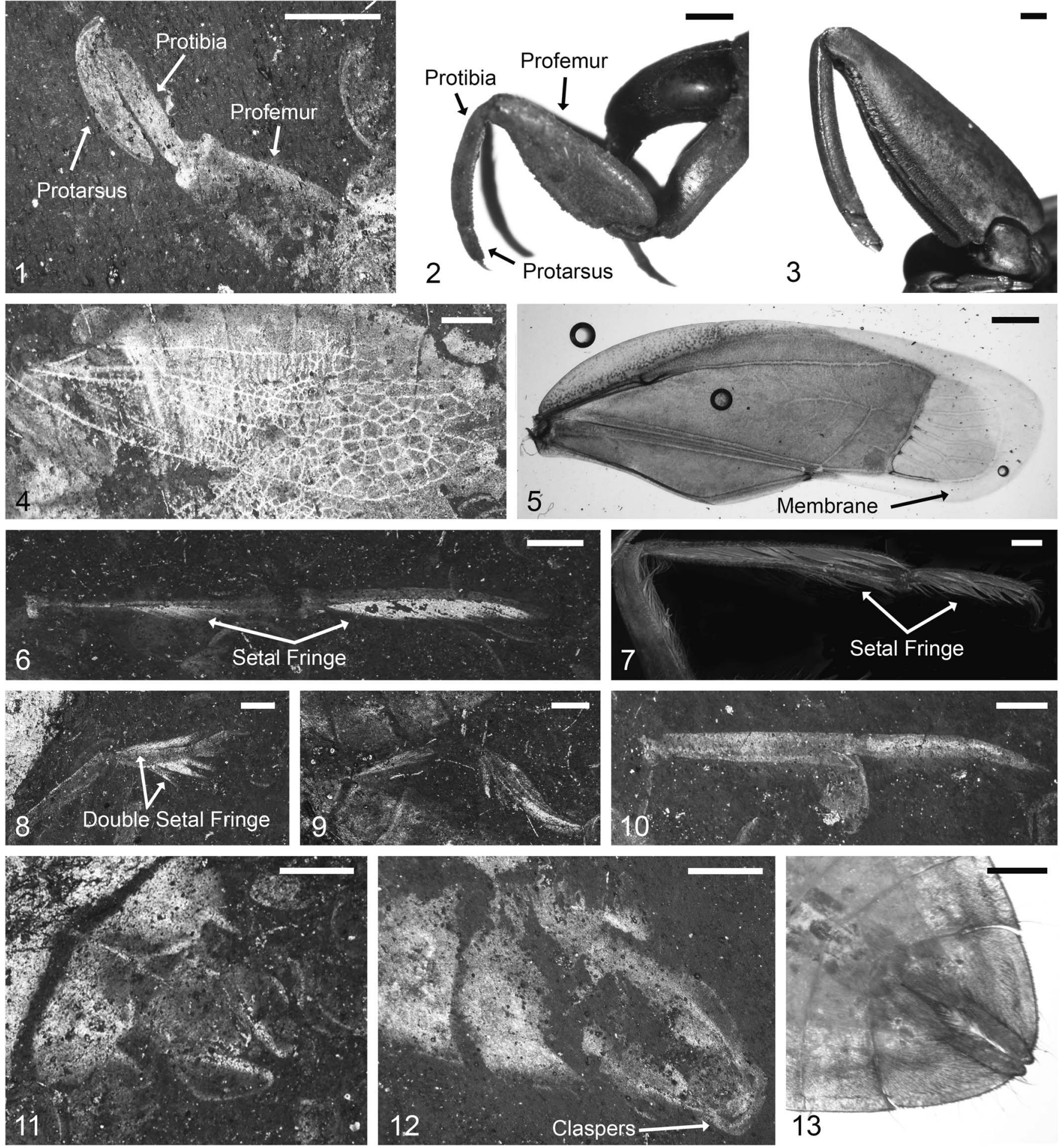

Figure 4. Morphological comparison of the forelegs, hemelytra, metathoracic legs, and terminalia of adult Triassonepa solensis $\mathrm{n}$. gen. $\mathrm{n}$. sp. and extant belostomatid species: (1) foreleg, VMNH 94671, holotype; (2) foreleg, Belostoma flumineum Say, 1832; (3) foreleg, Benacus griseus (Say, 1832) (formerly genus Lethocerus); (4) hemelytra, VMNH 53881; (5) hemelytra, Diplonychus urinator sudanensis Linnavuori, 1971; (6) setal fringe on metathoracic leg, VMNH 50230; (7) setal fringe on metathoracic leg, Belostoma elongatum Montandon, 1908; (8) double setal fringe on metathoracic leg, VMNH 90281; (9) double setal fringe on metathoracic leg, VMNH 90279; (10) metathoracic leg, VMNH 94671, holotype; (11) female terminalia, VMNH 90281; (12) male terminalia, VMNH 94671, holotype; (13) terminalia, Diplonychus urinator sudanensis Linnavuori, 1971. Scale bars are $1 \mathrm{~mm}$.

species. Measurements of body length, abdomen width, and tarsal length have shown that these two specimens have similar proportions to specimens with a single fringe, and therefore may be the same species.
The hemelytra of Triassonepa solensis $\mathrm{n}$. gen. n. sp. also provide good features for comparison to modern taxa. The hemelytra do not appear to cover the entire abdomen of any specimen, but this is likely an artifact of preservation (Fig. 4.4). 


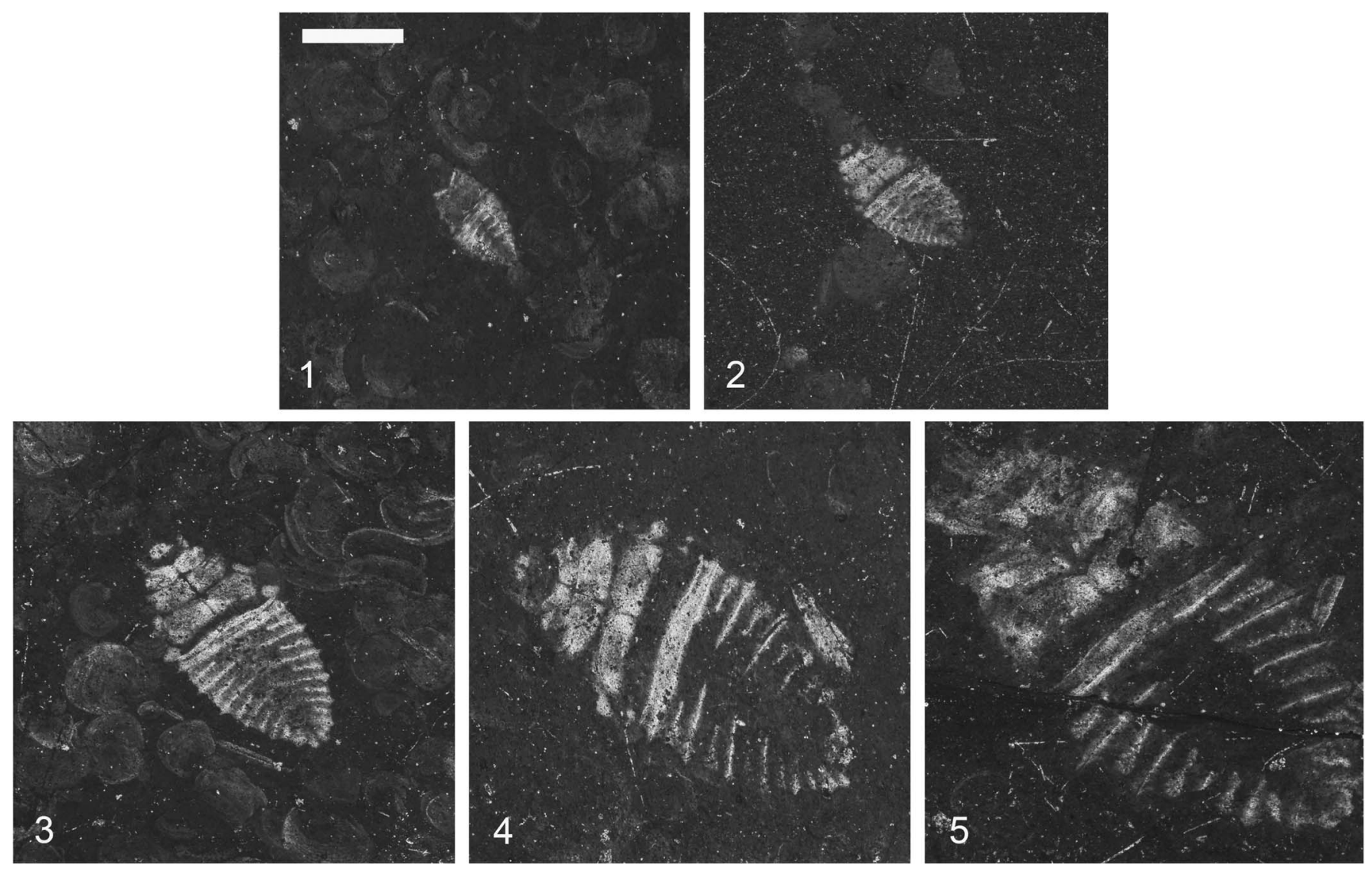

Figure 5. Triassonepa solensis $n$. gen. n. sp. growth series: (1) Instar I, VMNH 94575a; (2) Instar II, VMNH 50512; (3) Instar III, VMNH 53871; (4) Instar IV, VMNH 54155; (5) Instar V, VMNH 52498. Scale bar is $2 \mathrm{~mm}$, located in photo 1.

Because the apical parts of modern heteropteran hemelytra are thin and membranous, it is unlikely that these regions would have been preserved. In addition, the abdominal spiracles of T. solensis are located on its dorsal surface, which is typical of insects that breathe underwater via a plastron (a thin film of air held beneath the wings and used as a physical gill). In order for $T$. solensis to use a plastron, as is done by many modern aquatic insects including belostomatids (e.g., Abedus herberti Hildago, 1935; see Goforth and Smith, 2012), its hemelytra would need to fully cover its spiracles (i.e., to the edges of the abdomen).

The $8^{\text {th }}$ abdominal segment of Triassonepa solensis $\mathrm{n}$. gen. n. sp. contains two lateral, paddle-shaped lobes and two medial processes resembling respiratory tubes (Fig. 4.11). It is morphologically quite similar to the eighth abdominal segment of female naucorids (particularly Ilyocoris exclamationis Scott, 1874 as illustrated by Lee, 1991). This suggests that: (1) $T$. solensis occupies a very basal position within Belostomatidae, and (2) the majority of the preserved specimens were likely female. However, two specimens (VMNH 94671, Fig. 4.12, holotype; VMNH 94672, Fig. 2.4) possess terminalia with a slightly different structure. The $8^{\text {th }}$ abdominal segments of these specimens are more elongate and possess two apical, articulated appendages that resemble claspers. It is therefore likely that these two specimens are males.

Immature Triassonepa solensis $\mathrm{n}$. gen. $\mathrm{n}$. sp. were separated into instars based on total body lengths (Fig. 5). Because the head was not often preserved, there is a minor amount of uncertainty in some of the measurements. A total of 51 nymphs were measured from the anterior margin of the head to the apex of the abdomen, yielding five size classes (Fig. 6): Instar I, $1.6-2.3 \mathrm{~mm}$ (mean $2.0 \mathrm{~mm}$ ); Instar II, $2.6-3.4 \mathrm{~mm}$ (mean $3.0 \mathrm{~mm}$ ); Instar III, 4.0-5.2 mm (mean $4.6 \mathrm{~mm}$ ); Instar IV, 6.2-7.7 mm (mean 6.9 mm); Instar V, 9.5-10.3 mm (mean $9.9 \mathrm{~mm}$ ). Each instar was $~ 1.5 \mathrm{x}$ larger than the preceding one. Modern belostomatids also have five instars and show a similar growth ratio of 1.2-1.5 with each successive instar (Tables 2, 3). These ratios correspond to Dyar's Rule, which states that an insect instar is $\sim 1.4 \mathrm{x}$ the size of its previous instar.

\section{Discussion}

Belostomatid habitats.-Due to the presence of swimming fringes on the hind legs of Triassonepa solensis n. gen. n. sp., it is reasonable to assume that this species had similar physiology and behaviors to modern belostomatids. Understanding the habitats of these modern belostomatids has implications for determining the nature and chemistry of ancient 'Lake Solite.'

Belostomatids live in a wide variety of habitats, but are most commonly found in shallow bodies of water with marginal vegetation. Kashian and Burton (2000) reported Lethocerus sp. from the wetlands of northern Lake Huron in areas dominated by sedges. Belostomatids also occur in many of India's small freshwater lakes. Majumder et al. (2013), for example, found two genera (Lethocerus and Diplonychus) living in the marginal 


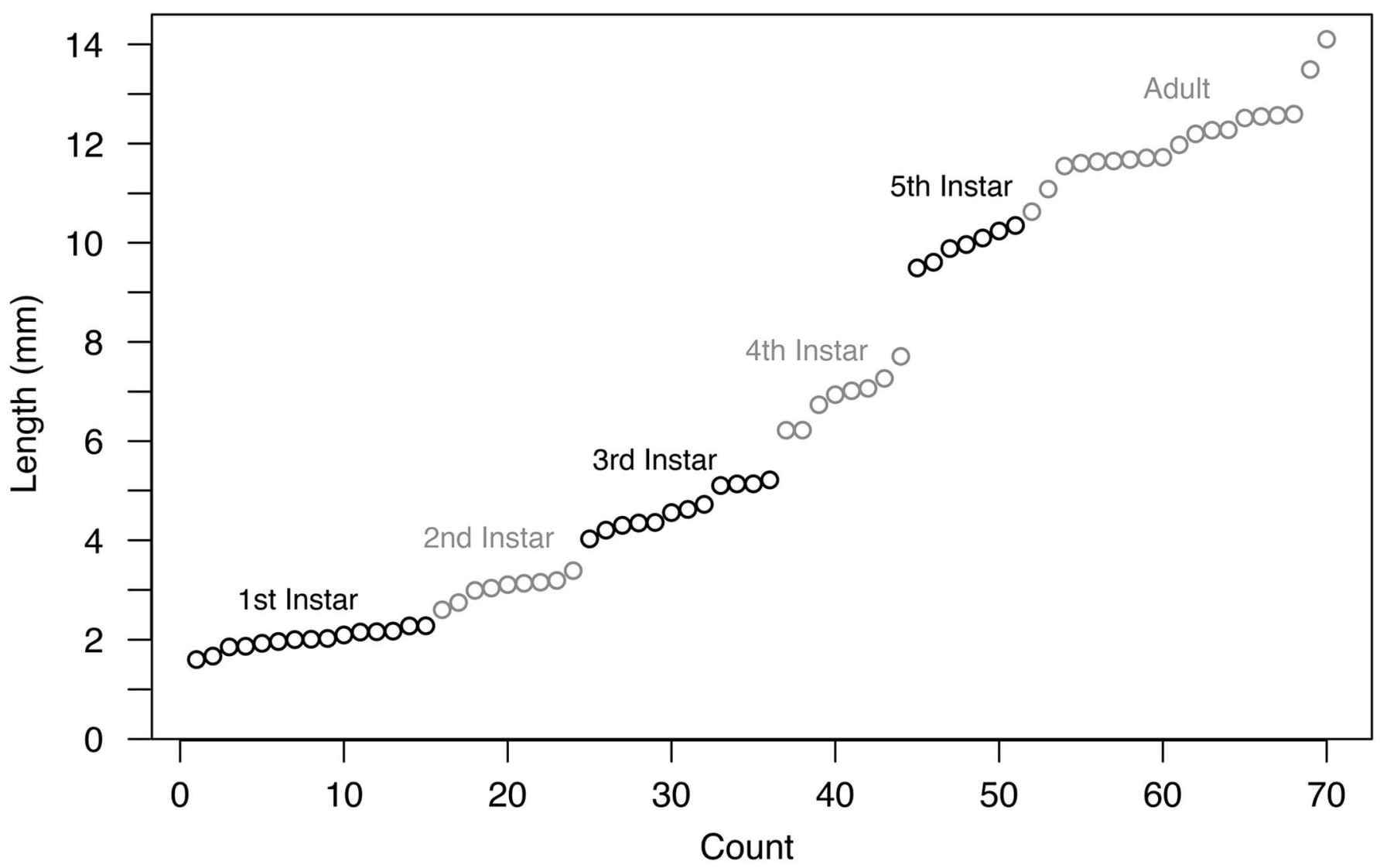

Figure 6. Lengths of Triassonepa solensis n. gen. n. sp. instars and adults: 70 specimens (51 nymphs, 19 adults) were measured. The two largest adult specimens are males.

Table 2. Mean lengths (in mm) of the five instars of Triassonepa solensis n. gen. n. sp. (this study), Lethocerus maximus (Cullen, 1969), L. mazzai (De Carlo, 1962), Hydrocyrius columbiae (Miller, 1961), Belostoma flumineum (Flosi, 1980), B. malkini (Cullen, 1969), and Abedus breviceps (Keffer and McPherson, 1988).

\begin{tabular}{lccccccc}
\hline & T. solensis & L. maximus & L. mazzai & H. columbiae & B. flumineum & B. malkini & A. breviceps \\
\hline Instar 1 & 2.0 & 15.0 & 11.0 & 16.0 & 4.6 & 7.75 & 6.4 \\
Instar 2 & 3.0 & 22.5 & 17.0 & 21.0 & 6.2 & 11.00 & 9.1 \\
Instar 3 & 4.6 & 32.5 & 26.0 & 28.5 & 9.0 & 15.50 & 11.3 \\
Instar 4 & 6.9 & 46.5 & 37.5 & 37.5 & 11.5 & 22.25 & 15.5 \\
Instar 5 & 9.9 & 67.5 & 53.0 & 50.5 & 16.5 & 32.50 & 20.0 \\
\hline
\end{tabular}

Table 3. Growth ratios Triassonepa solensis n. gen. n. sp. (this study), Lethocerus maximus (Cullen, 1969), L. mazzai (De Carlo, 1962), Hydrocyrius columbiae (Miller, 1961), Belostoma fumineum (Flosi, 1980), B. malkini (Cullen, 1969), and Abedus breviceps (Keffer and McPherson, 1988) (the same species as in Table 2), calculated by dividing instar length by length of the previous instar.

\begin{tabular}{lccccccc}
\hline & T. solensis & L. maximus & L. mazzai & H. columbiae & B. flumineum & B. malkini & A. breviceps \\
\hline Instar 2/1 & 1.50 & 1.50 & 1.55 & 1.31 & 1.35 & 1.42 & 1.42 \\
Instar 3/2 & 1.53 & 1.44 & 1.53 & 1.36 & 1.45 & 1.41 & 1.24 \\
Instar 4/3 & 1.50 & 1.43 & 1.44 & 1.32 & 1.28 & 1.44 & 1.37 \\
Instar 5/4 & 1.43 & 1.45 & 1.41 & 1.35 & 1.43 & 1.46 & 1.29 \\
\hline
\end{tabular}

vegetation of manmade, urban lakes in Tripura, northeastern India. Diplonychus rusticus Fabricius, 1781 was collected from both Pocharam Lake in southeastern India (Deepa and Rao, 2007), and Loktak Lake of northeastern India (Takhelmayum and Gupta, 2011). Loktak Lake is unique in its possession of phumdis, which are floating islands composed of vegetation, organic matter, and soil, among which belostomatids live. Belostomatids have also been collected from arid wetlands such as Bañado Carilauquen in west-central Argentina (Scheibler and
Ciocco, 2013). These semi-permanent wetlands are located near a shallow, saline lake, although the wetlands themselves have negligible salinity.

In addition to shallow lakes and wetland environments, belostomatids inhabit the marginal areas of deep lakes, such as Lake Victoria in Kenya (Muli and Mavuti, 2001; Orwa et al., 2015). Three species were identified there: Diplonychus sp. (formerly genus Sphaerodema), Hydrocyrius sp., and Lethocerus niloticus Stål, 1885. Similarly to Loktak Lake, 
Diplonychus sp. and Hydrocyrius sp. were found to inhabit the lake's floating hyacinth mats (Orwa et al., 2015).

Belostomatids are one of the few groups of aquatic insects that can tolerate agriculture-affected and polluted water bodies. Belostomatids inhabit the length of the Enfranz River in Ethiopia, from the clean headwaters to the agriculturedominated mouth (Mehari et al., 2014). Other nepomorphs, such as naucorids and nepids, were only found in the unaffected, upstream areas. Additionally, Belostoma sp. has been collected in the eutrophic Kipkaren River of Kenya (Aura et al., 2011) and Diplonychus sp. was found to inhabit the margins of a number of polluted Bangalore lakes in southern India (Balachandran and Ramachandra, 2010). Perhaps the most extreme case is the collection of Belostoma sp. from hydrogen sulfide-rich Cueva del Azufre in Tabasco, Mexico (Tobler et al., 2007).

Belostomatids are also known to inhabit temporary environments such as rain pools (Fontanarrosa et al., 2009), agricultural fields (Das and Gupta, 2010), rice paddies (Hendawy et al., 2005), and sinkholes (Blinn and Sanderson, 1989), and are common inhabitants of ephemeral playa lakes in arid environments (Haukos and Smith, 1992). Belostomatids have been collected in the stagnant 'buffalo-wading pools' of Tarangire National Park on the savanna of northern Tanzania (D.G., personal observation). Merickel and Wangberg (1981) collected Belostoma flumineum along the shores of two playas near Lubbock, Texas, and Richardson et al. (1972) found one juvenile belostomatid in the Jornada Playa of New Mexico. Adult belostomatids disperse to these ephemeral environments via flight, and as a result, are often found at bright lights during the night.

A few studies have even reported belostomatids inhabiting brackish waters. Angelin et al. (2010) collected Diplonychus sp. and Belostoma sp. from an estuary in southern India with a salinity of between $4 \%$ and $8 \%$ (ppt). Siddiqi (2008) reported belostomatids in the marginal areas of India's Lake Lonar, which is a hyperalkaline, saline, crater lake with a $\mathrm{pH}$ of $\sim 10.5$ (Siddiqi, 2008) and a salinity of up to $\sim 6 \%$ (Yannawar and Bhosle, 2013). However, Badve et al. (1993) report that the marginal areas of the lake near the inflow of the freshwater springs have a $\mathrm{pH}$ closer to 7.5. It is in these areas that the marshes exist, and it is likely that the belostomatids inhabit these more suitable areas.

Environmental interpretation of 'Lake Solite'.-Like their modern counterparts, many fossil belostomatids are reported from shallow, lacustrine paleoenvironments (e.g., Grimaldi and Maisey, 1990; Martínez-Delclòs et al., 1995; Prokop and $\mathrm{Nel}, 2000)$. However, this contrasts with both interpretations of the paleoenvironment of the Cow Branch Formation. Olsen et al. (1978) first described the environment as a large, deep, chemically stratified lake. This stratification would have produced anoxic bottom waters that prevented bioturbation and therefore allowed for exquisite fossil preservation of delicate insects such as midges and tiny hemipterans. Although unusual for a modern belostomatid habitat, other deep lacustrine paleoenvironments have been reported to contain belostomatid fossils. One such deposit, the late Oligocene Enspel Formation of Germany (Poschmann et al., 2010), has produced ten belostomatid fossils, four of which are adult specimens (Wedmann, 2000).
Recent research by Liutkus et al. (2010) proposed that the Cow Branch Formation was a shallow, alkaline, saline, rift valley lake. They presented a number of reasons for this interpretation: (1) dominance of terrestrial and nearshoredwelling insects and terrestrial vascular plants, (2) exquisite fossil preservation, and (3) presence of dolomite and absence of quartz and zirconium throughout the deposit.

Based on the environmental preferences of modern belostomatids, their abundance in the Cow Branch Formation would indicate a shallow, nearshore paleoenvironment. The tolerance of modern belostomatids for polluted and harsh water conditions suggests they may have also been tolerant to extreme environments such as saline, alkaline, rift valley lakes. Because belostomatids breathe air, they would be unaffected by poor water quality. However, harsh water conditions would affect organisms possessing gill respiration (i.e., Ephemeroptera, Plecoptera, Odonata, Trichoptera, etc.), so the lack of gilled insect nymphs of these orders within the deposit is good evidence for poor water quality. The only gilled insect order reported from the Cow Branch Formation is Diptera (Liutkus et al., 2010). However, this appears to be a misidentification of the enigmatic, gilled, larva-like arthropod, which may actually be a crustacean.

In addition to belostomatids, the insects preserved in the Cow Branch Formation are mostly terrestrial adults from the orders Hemiptera (Sternorrhyncha), Diptera, and Coleoptera. A few other taxa have been found to date, including adult members of Blattodea, Odonata, Orthoptera, Plecoptera (Fraser and Grimaldi, 2003), Thysanoptera (Grimaldi et al., 2004), Mecopterida (Grimaldi et al., 2005), Amphiesmenoptera, and Neuroptera. This unique assemblage of terrestrial insects further suggests that the water was toxic to gill-possessing, aquatic larvae and other sensitive groups. Moreover, Fraser and Grimaldi (1999) noted the abundance of conchostracans within the insect bed. Modern members of this group are most commonly found in ephemeral, alkaline water bodies (Tasch, 1969).

Liutkus et al. (2010) discussed the exquisite preservation of the insect fossils as evidence for a shallow lake. Most insects are completely articulated, which is quite rare for Triassic fossils (cf., Riek, 1974; Brauckmann and Schlüter, 1993; Shcherbakov et al., 1995; Martins-Neto et al., 2008). The lack of disarticulation suggests limited postmortem movement. If the lake had been as deep as originally suggested, the insects would likely have decayed, disarticulated, or have been eaten before settling to the benthic zone. Moreover, there are no fossil fish found in the insect layers, further evidence that the insects were buried in very shallow water.

The geochemistry of the deposit also supports the interpretation of a saline, alkaline lake. Liutkus et al. (2010) reported dolomitic claystone throughout the insect bed, and in modern lakes primary precipitation of dolomite occurs most often in waters with elevated salinity, alkalinity, and with abundant magnesium and calcium (DeDeckker and Last, 1989). Furthermore, the surrounding basin is rich in quartz, making its absence in the Cow Branch deposit significant. In addition, albite is abundant in the deposit (Liutkus et al., 2010), which is proposed to have formed by the reaction of clay, quartz, and sodium under alkaline conditions (van de Kamp and Leake, 
1996). The deposit is also depleted in zirconium. Ayers and Zhang (2005) have demonstrated that this element dissolves in alkaline conditions. These three geochemical conditions support a saline, alkaline environment during the time of deposition.

Although most fossil belostomatids have been reported from shallow, non-saline, lacustrine environments, Polhemus (2000) reported fossils from a saline environment, the Jurassic Todilto Formation of New Mexico. This formation is interpreted as a paralic, saline playa due to its interfingered marine and continental sediments (Lucas et al., 2000). Although this interpretation is somewhat controversial, the water chemistry in this type of environment may have been similar to that proposed by Liutkus et al. (2010) for the Cow Branch Formation. Vega et al. (2006) gave a second example of a potentially saline belostomatid habitat from the Early Cretaceous Sierra Madre Formation of southeastern Mexico, which has been interpreted as a brackish marginal lagoon or estuary. Due to the wide environmental tolerances of both fossil and modern belostomatids, the dominance of terrestrial adult insects and lack of aquatic nymphs, the abundance of conchostracans, the exquisite preservation of the Solite fossils, and the geochemistry of the Cow Branch Formation, it is very likely that 'Lake Solite' was a shallow, saline, alkaline rift valley lake.

\section{Acknowledgments}

J.C. is grateful to the American Museum of Natural History Grants Program for the Theodore Roosevelt Memorial Grant, which provided the funding necessary to visit and collect at the Solite deposit. J.C. is especially grateful to C. Byrd for hosting her visits to the Virginia Museum of Natural History and to $\mathrm{R}$. Vodden (VMNH) for allowing her to participate in the fossil excavation at the Solite deposit. We are grateful for the thoughtful commentary on this manuscript provided by B.W. Smith and an anonymous reviewer. Financial research support for this project came from a Graduate Teaching Assistantship from the Department of Earth and Planetary Sciences, Rutgers University.

\section{References}

Amyot, C.J.-B., and Serville, A., 1843, Histoire naturelle des insectes Hémiptères: Paris, Librairie Encyclopédique de Roret, 675 p.

Angelin, J.A., Jehamalar, E.E., Das, S.S.M., and Kumar, S.P., 2010, Effect of salinity on the distribution of aquatic insects of Manakudy Estuary, Kanyakumari District: Journal of Basic and Applied Biology, v. 4, p. 91-97.

Aura, C.M., Raburu, P.O., and Herrmann, J., 2011, Macroinvertebrates' community structure in Rivers Kipkaren and Sosiani, River Nzoia basin, Kenya: Journal of Ecology and the Natural Environment, v. 3, p. 39-46.

Ayers, J.C., and Zhang, L., 2005, Zircon aqueous solubility and partitioning systematics: Goldschmidt Conference Abstracts, Moscow, v. 15, p. A5.

Badve, R.M., Kumaran, K.P.N., and Rajshekhar, C., 1993, Eutrophication of Lonar Lake, Maharashtra: Current Science, v. 65, p. 347-351.

Balachandran, C., and Ramachandra, T.V., 2010, Aquatic macroinvertebrate diversity and water quality of Bangalore lakes. Lake 2010: Wetlands, Biodiversity and Climate Change, 22-24 December, Satish Dhawan Auditorium, Indian Institute of Science, Bangalore, p. 1-18. http://wgbis.ces.iisc. ernet.in/energy/lake2010/Theme 1/balachandran.pdf

Blinn, D.W., and Sanderson, M.W., 1989, Aquatic insects in Montezuma Well, Arizona, USA: a travertine spring mound with high alkalinity and dissolved carbon dioxide: The Great Basin Naturalist, v. 49, p. 85-88.

Brauckmann, C., and Schlüter, T., 1993, Neue Insekten aus der Trias von Unter-Franken: Geologica et Palaeontologica, v. 27, p. 181-199.
Brożek, J., 2014, Phylogenetic signals from Nepomorpha (Insecta: Hemiptera: Heteroptera) Mouthparts: Stylets Bundle, Sense Organs, and Labial Segments: The Scientific World Journal, v. 2014, p. 1-30.

Chou, I., and Hong, Y., 1989, An Early Cretaceous new genus and species in Shaanganning Basin (Insecta: Heteroptera): Entomotaxonomia, v. 11, p. 197-205. [in Chinese with English Summary]

Cullen, M.J., 1969, The biology of giant water bugs (Hemiptera: Belostomatidae) in Trinidad: Proceedings of the Royal Entomological Society of London, Series A, v. 44, p. 123-136.

Das, K., and Gupta, S., 2010, Aquatic Hemiptera community of agricultural fields and rain pools in Cachar District, Assam, North East India: Assam University Journal of Science and Technology, v. 5, p. 123-128.

De Carlo, J.M., 1962, Consideraciones sobre la biologia de Lethocerus mazzai De Carlo (Hemiptera: Belostomatidae): Physis, v. 23, p. 143-151.

De Deckker, P., and Last, W.M., 1989, Modern, non-marine dolomite in evaporitic playas of western Victoria, Australia: Sedimentary Geology, v. 64, p. $223-238$

Deepa, J., and Rao, C.A.N., 2007, Aquatic Hemiptera of Pocharam Lake, Andhra Pradesh: Zoos' Print Journal, v. 22, p. 2937-2939.

Evans, J.W., 1943, Upper Permian Homoptera from New South Wales: Records of the Australian Museum, v. 21, p. 180-198

Evans, J.W., 1950, A re-examination of an Upper Permian insect, Paraknightia magnifica Ev: Records of the Australian Museum, v. 22, p. 246-250.

Fabricius, J.C., 1781, Species Insectorum Exhibentes Eorum Differntias Specificas, Synonyma Auctorum, Loca Natalia, Metamorphosis Adjectis Observationibus, Descriptionibus: Hafniae, Proft et Storch, v. 2, 517 p.

Flosi, J.W., 1980, The population biology of the giant water bug Belostoma flumineum Say (Hemiptera: Belostomatidae) [Ph.D. Thesis]: Ames, Iowa, Iowa State University, $161 \mathrm{p}$.

Fontanarrosa, M.S., Collantes, M.B., and Bachmann, A.O., 2009, Seasonal patterns of the insect community structure in urban rain pools of temperate Argentina: Journal of Insect Science, v. 9, p. 1-17.

Fraser, N.C., and Grimaldi, D.A., 1999, A significant late Triassic Lagerstätte from Virginia, USA: Rivista del Museo Civico di Scienze Naturali "Enrico Caff" v. 20 (supplement), p. 79-84.

Fraser, N.C., and Grimaldi, D.A., 2003, Late Triassic continental faunal change: New perspectives on Triassic insect diversity as revealed by a locality in the Danville Basin, Virginia, Newark Supergroup, in Letourneau, P.M., and Olsen, P.E., eds., The Great Rift Valleys of Pangea in Eastern North America: New York, Columbia University Press, v. 2, p. 192-205.

Fraser, N.C., Grimaldi, D.A., Olsen, P.E., and Axsmith, B., 1996, A Triassic Lagerstätte from eastern North America: Nature, v. 380, p. 615-619.

Fraser, N.C., Olsen, P.E., Dooley, A.C. Jr., and Ryan, T.R., 2007, A new gliding tetrapod (Diapsida: ?Archosauromorpha) from the Upper Triassic (Carnian) of Virginia: Journal of Vertebrate Paleontology, v. 27, p. 261-265.

Germar, E.F., 1839, Die versteinerten Insecten Solenhofens: Nova Acta Physico-Medica Academiae Caesareae Leopoldino-Carolinae Naturae Curiosum, v. 19, p. 187-222.

Goforth, C.L., and Smith, R.L., 2012, Subsurface behaviours facilitate respiration by a physical gill in an adult giant water bug, Abedus herberti: Animal Behaviour, v. 83, p. 747-753.

Goodwyn, P.J.P., 2006, Taxonomic revision of the subfamily Lethocerinae Lauck \& Menke (Heteroptera: Belostomatidae): Stuttgarter Beiträge zur Naturkunde, Serie A (Biologie), v. 695, p. 1-71.

Grimaldi, D., and Engel, M.S., 2005, Evolution of the Insects: New York, Cambridge University Press, $772 \mathrm{p}$.

Grimaldi, D., and Maisey, J., 1990, Introduction, in Grimaldi, D.A., ed., Insects from the Santana Formation, Lower Cretaceous, of Brazil: Bulletin of the American Museum of Natural History, p. 5-14.

Grimaldi, D., Shmakov, A., and Fraser, N., 2004, Mesozoic thrips and early evolution of the order Thysanoptera (Insecta): Journal of Paleontology, v. 78, p. $941-952$.

Grimaldi, D., Junfeng, Z., Fraser, N.C., and Rasnitsyn, A., 2005, Revision of the bizarre Mesozoic scorpionflies in the Pseudopolycentropodidae (Mecopteroidea): Insect Systematics \& Evolution, v. 36, p. 443-458.

Haukos, D.A., and Smith, L.M., 1992, Ecology of Playa Lakes: Waterfowl Management Handbook, Paper 19, p. 1-7.

Hendawy, A.S., Sherif, M.R., Abada, A.E., and El-Habashy, M.M., 2005, Aquatic and semi-aquatic insects occurring in the Egyptian rice fields and hazardous effect of insecticides: Egyptian Journal of Agricultural Research, v. 83 , p. $493-502$.

Hildago, J., 1935, The genus Abedus Stål (Hemiptera, Belostomatidae): The University of Kansas Science Bulletin, v. 22, p. 493-519.

Kashian, D.R., and Burton, T.M., 2000, A comparison of macroinvertebrates of two Great Lakes coastal wetlands: testing potential metrics for an index of ecological integrity: Journal of Great Lakes Research, v. 26, p. 460-481.

Keffer, S.L., and McPherson, J.E., 1988, Descriptions of nymphal instars of Abedus breviceps (Hemiptera: Belostomatidae): Great Lakes Entomologist, v. 21 , p. $169-174$. 
Lakshminarayana, K.V., 1984, On some fossil Cryptocerata (Heteroptera: Insecta) with description of a new genus et species: Bulletin of the Zoological Survey of India, v. 5, p. 153-158.

Laporte, F., 1833, Essai d'une classification systématique de l'ordre de Hémiptères (Hémiptères Hétéroptères, Latr.): Guerin Magasin de Zoologie, v. 2 , p. $1-88$.

Larsson, S.G., 1975, Palaeobiology and mode of burial of the insects of the Lower Eocene Mo-clay of Denmark: Bulletin of the Geological Society of Denmark, v. 24, p. 193-209.

Latreille, P.A., 1802, Histoire naturelle, generale et particulière des crustaces et des insects, v. 3: Paris, F. Dufart, 467 p.

Latreille, P. A., 1807, Genera crustaceorum et insectorum secundum ordinem naturalem in familias disposita, Iconibus Exemplisque Plurimus Explicata, v. 3: Paris, Amand Kønig, 258 p.

Latreille, P.A., 1810, Considérations générales sur ll'ordre naturel des animaux: Paris, F. Schoell, 444 p.

Lauck, D.R., and Menke, A.S., 1961, The higher classification of the Belostomatidae (Hemiptera): Annals of the Entomological Society of America, v. 54 , p. $644-657$.

Leach, W.E., 1815, Entomology, in Brewster, D., ed., The Edinburgh Encyclopaedia: Edinburgh, Blackwood, v. 9, p. 57-172.

Lee, C.E., 1991, Morphological and phylogenetic studies on the true water bugs (Hemiptera: Heteroptera): Nature and Life, v. 21, 183 p.

Leidy, J., 1847, History and anatomy of the hemipterous genus Belostoma: Journal of the Academy of Natural Sciences of Philadelphia, v. 2, p. 57-67.

Linnavuori, R., 1971, Hemiptera of the Sudan, with remarks on some species of the adjacent countries. I. The aquatic and subaquatic families: Annales Zoologici Fennici, v. 8, p. 340-366.

Liutkus, C.M., Beard, J.S., Fraser, N.C., and Ragland, P.C., 2010, Use of fine-scale stratigraphy and chemostratigraphy to evaluate conditions of deposition and preservation of a Triassic Lagerstätte, south-central Virginia: Journal of Paleolimnology, v. 44, p. 645-666.

Lucas, S.G., Rinehart, L.F., and Estep, J.W., 2000, Paleoecological significance of Middle Jurassic insect locality, Todilto Formation, north-central New Mexico, in Lucas, S.G., ed., New Mexico's Fossil Record: New Mexico Museum of Natural History and Science, Bulletin 16, p. 29-40.

Mahner, M., 1993, Systema Cryptoceratorum Phylogeneticum (Insecta, Heteroptera): Zoologica, v. 143, 302 p.

Majumder, J., Das, R.K., Majumder, P., Ghosh, D., and Agarwala, B.K., 2013 Aquatic insect fauna and diversity in urban fresh water lakes of Tripura, northeast India: Middle-East Journal of Scientific Research, v. 13 p. 25-32.

Martínez-Delclòs, X., Nel, A., and Popov, Y.A., 1995, Systematics and functional morphology of Iberonepa romerali n. gen. and sp., Belostomatidae from the Spanish Lower Cretaceous (Insecta, Heteroptera): Journal of Paleontology, v. 69, p. 496-508.

Martins-Neto, R.G., Gallego, O.F., and Zavattieri, A.M., 2008, The Triassic insect fauna from Argentina: Coleoptera, Hemiptera and Orthoptera from the Potrerillos Formation, south of Cerro Cacheuta, Cuyana basin: Alavesia, v. 2 , p. $47-58$.

Mayr, G.L., 1853, Zwei neue Wanzen aus Kordofan, Limnogeton fieberi u. Lethrocerus cordofanus: Verhandlungen der Zoologisch-Botanischen Gesellschaft in Wien, v. 2, p. 14-18.

Mehari, A.K., Wondie, A., Mingist, M., and Vijverberg, J., 2014, Spatial and seasonal variation in the macro-invertebrates and physico-chemical parameters of the Enfranz River, Lake Tana sub-basin (Ethiopia): Ecohydrology \& Hydrobiology, v. 14, p. 304-312.

Merickel, F.W., and Wangberg, J.K., 1981, Species composition and diversity of macroinvertebrates in two playa lakes on the Southern High Plains, Texas: The Southwestern Naturalist, v. 26, p. 153-158.

Miller, P.L., 1961, Some features of the respiratory system of Hydrocyrius columbiae Spin. (Belostomatidae, Hemiptera): Journal of Insect Physiology, v. 6, p. 243-271.

Miller, S.E., 1983, Late Quaternary insects of Rancho La Brea and McKittrick, California: Quaternary Research, v. 20, p. 90-104.

Mitchell, P., and Wighton, D., 1979, Larval and adult insects from the Paleocene of Alberta, Canada: The Canadian Entomologist, v. 111, p. 777-782.

Montandon, A.L., 1908, Nouvelles espèces d Hémiptères aquatiques: Annales Historico Naturales-Musei Nationalis Hungarici, v. 6, p. 299-304.

Montandon, A.L., 1909, Belostomidae et Nepidae, Notes diverses et descriptions d'espèces nouvelles: Bulletin de la Société des Sciences, Bucarest, v. 18 , p. $137-147$.

Montandon, A.L., 1911, Deux genres nouveaux d Hydrocorises: Annals of the Museum Nationalis Hungarici, v. 9, p. 244-250.

Montandon, A.L., 1913, Nepidae et Belostomatidae, Descriptions de deux espèces nouvelles: Bulletin de la Société des Sciences de BucarestRoumanie, v. 22, p. 122-125.

Muli, J.R., and Mavuti, K.M., 2001, The benthic macrofauna community of Kenyan waters of Lake Victoria: Hydrobiologia, v. 458, p. 83-90.
Nel, A., and Paicheler, J.C., 1992, Les Heteroptera aquatiques fossiles, état actuel des connaissances (Heteroptera: Nepomorpha et Gerromorpha): Entomologica Gallica, v. 3, p. 159-182.

Nel, A., and Waller, A., 2006, A giant water bug from the Lower Cretaceous Crato Formation of Brazil (Heteroptera: Belostomatidae: Lethocerinae): Zootaxa, v. 1220, p. 63-68.

Olsen, P.E., 1979, A new aquatic eosuchian from the Newark Supergroup (Late Triassic-Early Jurassic) of North Carolina and Virginia: Postilla, v. 176, p. $1-14$.

Olsen, P.E., Remington, C.L., Cornet, B., and Thomson, K.S., 1978, Cyclic change in Late Triassic lacustrine communities: Science, v. 201, p. 729-733.

Orwa, P.O., Omondi, R., Ojwang, W., and Mwanchi, J., 2015, Diversity, composition and abundance of macroinvertebrates associated with water hyacinth mats in Lake Victoria, Kenya: African Journal of Environmental Science and Technology, v. 9, p. 202-209.

Polhemus, J.T., 1995, Nomenclatural and synonymical notes on the genera Diplonychus Laporte and Appasus Amyot and Serville (Heteroptera: Belostomatidae): Proceedings of the Entomological Society of Washington, v. 97, p. 649-653.

Polhemus, J.T., 2000, North American Mesozoic aquatic Heteroptera (Insecta, Naucoroidea, Nepoidea) from the Todilto Formation, New Mexico, in Lucas, S.G., ed., New Mexico's Fossil Record: New Mexico Museum of Natural History and Science, Bulletin 16. p. 29-40.

Popov, Y.A., 1968, True bugs of the Jurassic Karatau fauna (Heteroptera), in Jurassic insects of Karatau, Bulletin of the Academy of Sciences of the USSR, Section of General Biology, Nauka Press, Moscow, p. 99-113. [in Russian]

Popov, Y.A., 1971, Istoricheskoe razvitie poluzhestkokrylykh infraotryada Nepomorpha (Heteroptera) [Historical Development of True Bugs of the Infraorder Nepomorpha (Heteroptera)]: Trudy Paleontologicheskogo Instituta, Akademiya Nauk SSSR, v. 129, 230 p. [in Russian]

Popov, Y.A., 1989, New fossil Hemiptera (Heteroptera + Coleorrhyncha) from the Mesozoic of Mongolia: Neues Jahrbuch für Geologie und Paläontologie, Monatshefte, v. 3, p. 166-181.

Popov, Y.A., 1996, The first record of a fossil water bug from the Lower Jurassic of Poland (Heteroptera: Nepomorpha: Belostomatidae): Polskie Pismo Entomologiczne, v. 65, p. 101-105.

Popov, Y.A., Dolling, W.R., and Whalley, P.E.S., 1994, British Upper Triassic and Lower Jurassic Heteroptera and Coleorrhyncha (Insecta: Hemiptera) Genus, International Journal of Invertebrate Taxonomy, v. 5, p. 307-347.

Popov, Y.A., Rust, J., and Brauckmann, C., 2000, Insektenreste (Hemiptera: Belostomatidae; Coleoptera) aus dem Ober-Jura ("Kimmneridge") von Nettelstedt (Wiehengebirge, NW-Deutschland) [Insect remains (Hemiptera: Belostomatidae; Coleoptera) from the Upper Jurassic ("Kimmeridgian") of Nettelstedt (Wiehengebirge, NW Germany)]: Neues Jahrbuch für Geologie und Paläontologie-Monatshefte, v. 2, p. 83-92.

Poschmann, M., Schindler, T., and Uhl, D., 2010, Fossil-Lagerstätte Enspel-a short review of current knowledge, the fossil association, and a bibliography: Palaeobiodiversity and Palaeoenvironments, v. 90, p. 3-20.

Prokop, J., and Nel, A., 2000, First record of the genus Lethocerus Mayr, 1853 , from the Lower Miocene of the Most Formation in northern Bohemia, Czech Republic (Heteroptera, Belostomatidae): Bulletin de la Société entomologique de France, v. 105, p. 491-495.

Richardson, G., Ward, C.R., and Huddleston, E.W., 1972, Aquatic Macroinvertebrates of the Playa: U.S. International Biological Program, Desert Biome, Logan, UT, RM, v. 72-53, p. 2.2.2.4-70-2.2.2.4-95.

Riek, E.F., 1974, Upper Triassic insects from the Molteno "Formation", South Africa: Palaeontology of Africa, v. 17, p. 19-31.

Říha, P., and Kukalová, J., 1967, Eine neue tertiäre Wasserwanze aus dem Bechlejovicer Diatomit (Heteroptera, Belostomatidae): Acta Entomologica Bohemoslovaca, v. 64, p. 259-260.

Rust, J., and Ansorge, J., 1996, Bemerkenswerte Moler-Insekten: Fossilien, v. 1996 , p. $359-364$.

Say, T., 1832, Descriptions of new species of Heteropterous Hemiptera of North America: New Harmony, Indiana, 39 p. [p. 1-4 issued 1831]

Scheibler, E.E., and Ciocco, N.F., 2013, Diversity of aquatic insects and other associated macroinvertebrates in an arid wetland (Mendoza Province, Argentina): Revista De La Sociedad Entomologica Argentina, v. 72, p. 41-53.

Schuh, R.T., and Slater, J.A., 1995, True Bugs of the World (Hemiptera: Heteroptera): Classification and Natural History: New York, Cornell University Press, $336 \mathrm{p}$.

Scott, J., 1874, On a collection of Hemiptera Heteroptera from Japan. Descriptions of various new genera and species: Annual Magazine of Natural History, Series 4, v. 14, p. 289-452.

Shcherbakov, D.E., 2010, The earliest true bugs and aphids from the Middle Triassic of France (Hemiptera): Russian Entomological Journal, v. 19, p. $179-182$. 
Shcherbakov, D.E., Lukashevich, E.D., and Blagoderov, V.A., 1995, Triassic Diptera and initial radiation of the order: International Journal of Dipterological Research, v. 6, p. 75-115.

Siddiqi, S.Z., 2008, Limnological profile of high-impact meteor crater Lake Lonar, Buldana, Maharashtra, India, an extreme hyperalkaline, saline habitat, in Sengupta, M., and Dalwani, R., ed., Proceedings of Taal 2007 The $12^{\text {th }}$ World Lake Conference, p. 1597-1613.

Smith, R.L., 1997, Evolution of paternal care in the giant water bugs (Heteroptera: Belostomatidae) in Choe, J.C., and Crespi, B.J., The Evolution of Social Behavior in Insects and Arachnids: New York, Cambridge University Press, p. 116-149.

Spinola, M. 1850, Tavola sinottica dei generi spettanti alla classe de gli insetti arthrodignati Hemiptera Linn., Latr., Rhyngota Fabr., Rhynchota Burm. Modena, 60 p. [Republished 1852, Memorie di matematica e di fisica della Societá italiana delle Scienze Modena, v. 25, p. 43-100.]

Stål, C., 1855, Nya Hemiptera. Öfversigt af Kongl: Vetenskaps-Akademiens Förhandlingar, v. 11, p. 231-255.

Stål, C., 1861, Nova methodus familias quasdam Hemipterorum disponendi: Öfversigt af Kongliga Vetenskaps-Akademiens Förhandlingar, v. 18, p. $195-212$.

Stål, C., 1862, Hemiptera Mexicana enumeravit species-que novas descripsit Stettin Entomologische Zeitung Herausgegeben von dem Entomologischen Vereine zu Stettin, v. 23, 461 p.

Takhelmayum, K., and Gupta, S., 2011, Distribution of aquatic insects in phumdis (floating island) of Loktak Lake, Manipur, northeastern India: Journal of Threatened Taxa, v. 3, p. 1856-1861.

Tasch, P., 1969, Branchiopoda, in Moore, R.C., ed., Treatise on Invertebrate Paleontology, Pt. R, Arthropoda, v. 4: Boulder, Colorado and Lawrence, Kansas, Geological Society of America, Inc. and University of Kansas Press, p. R128-R191.

Tobler, M., Schlupp, I., and Plath, M., 2007, Predation of a cave fish (Poecilia mexicana, Poeciliidae) by a giant water-bug (Belostoma, Belostomatidae) in a Mexican sulphur cave: Ecological Entomology, v. 32, p. 492-495. van de Kamp, P.C., and Leake, B.E., 1996, Petrology, geochemistry, and $\mathrm{Na}$ metasomatism of Triassic-Jurassic non-marine clastic sediments in the Newark, Hartford, and Deerfield rift basins, northeastern USA: Chemical Geology, v. 133, p. 89-124.

Vega, F.J., García-Barrera, P., Perrilliat, M.D.C., Coutiño, M.A., and Mariño-Pérez, R., 2006, El Espinal, a new plattenkalk facies locality from the Lower Cretaceous Sierra Madre Formation, Chiapas, southeastern Mexico: Revista Mexicana de Ciencias Geológicas, v. 23, p. 323-333.

Voelker, V.J., 1968, Untersuchungen zu Ernährung, Fortpflanzungsbiologie und Entwicklung von Limnogeton fieberi Mayr (Belostomatidae, Hemiptera) als Beitrag zur Kenntnis von natürlichen Feinden tropischer Süßwasserschnecken: Entomologische Mitteilungen asu dem Zoologischen Staatsinstitut u. Zoologischen Museum Hamburg, v. 3, p. 1-24.

Wedmann, S., 2000, Die Insekten der oberoligozänen Fossillagerstätte Enspel (Westerwald, Deutschland): Systematik, Biostratonomie und Paläoökologie: Mainzer Naturwissenschaftliches Archiv, v. 23, 154 p.

Yannawar, V.B., and Bhosle, A.B., 2013, Cultural Eutrophication of Lonar Lake, Maharashtra, India: International Journal of Innovation and Applied Studies, v. 3, p. 504-510.

Zamboni, J.C., 2001, Contribution to the knowledge of the aquatic paleoentomofauna from Santana Formation (Araripe Basin, Lower Cretaceous, northeast Brazil) with description of new taxa: Acta Geologica Leopoldensia, v. 24, p. 129-135.

Zhang, J., 1989, Fossil Insects from Shanwang, Shandong, China: Jinan, China, Shandong Science and Technology Publishing House, 459 p. [in Chinese with English summary]

Zhang, J.S.B., and Zhang, X., 1994, Miocene Insects and Spiders from Shanwang, Shandong: Beijing, China, Science Press, 298 p. [in Chinese with English summary]

Accepted 26 May 2017 